\title{
Effects of phytase on pig diets digestibilities, bone mineral deposition, performance and manure production
}

\author{
Efeitos da fitase sobre digestibilidades de dietas, deposição de \\ minerais nos ossos, desempenho e produção de dejetos por suínos
}

\author{
Henrique Gonsales de Faria ${ }^{1}$; Maria Cristina Thomaz²; Urbano dos Santos Ruiz ${ }^{3 *}$ \\ Rizal Alcides Robles-Huaynate ${ }^{4}$; Pedro Henrique Watanabe ${ }^{5}$; \\ Gabriel Maurício Peruca de Melo ${ }^{6}$, Susana Zaneti da Silva ${ }^{1}$
}

\begin{abstract}
Two trials were conducted to evaluate phytase addition to diets with corn, rice and soybean meals for swine. In the first trial, the digestibilities of gross energy and crude protein and the availabilities of calcium $(\mathrm{Ca})$ and phosphorous $(\mathrm{P})$ of diets with or without phytase were evaluated in growing barrows (BW $20.42 \pm 2.45 \mathrm{~kg}$ ), using the total feces and feed collection methods. In the second trial, the parameters evaluated were pig performance, mineral contents in the $3 \mathrm{rd}$ and 4 th metacarpals, feces production and composition of growing and finishing gilts fed one of the following diets: Positive control (PC), formulated to achieve nutrient and energy requirements of growing and finishing gilts; Negative control (NC), diet PC meeting $84 \%$ and $65 \%$ of $\mathrm{Ca}$ and $\mathrm{P}$ levels, respectively; Negative control + phytase $(\mathrm{PHY})$, diet $\mathrm{NC}+0.01 \%$ phytase $(500 \mathrm{FTU} / \mathrm{kg})$. Phytase addition improved $\mathrm{P}$ and $\mathrm{Ca}$ availabilities in $14.34 \%$ and $4.08 \%$, respectively, compared with the diet with no phytase, in trial one. In trial two, the deposition of zinc in the metacarpals was improved by the enzyme and $\mathrm{Ca}, \mathrm{P}$ and copper fecal excretions of the animals from the PC diet were greater than that observed for the PHY animals. Phytase addition improved the use of phytic phosphorous and calcium by the pigs and is recommended as a way to reduce the potential environmental impact of swine production.
\end{abstract}

Key words: Calcium, environmental pollution, enzyme, piglets, phosphorous

\section{Resumo}

Foram realizados dois experimentos com objetivo de avaliar a adição de fitase a dietas contendo milho e farelos de arroz integral e de soja para suínos. No primeiro experimento foram avaliadas as digestibilidades da energia e proteína brutas e as disponibilidades do cálcio $(\mathrm{Ca})$ e do fósforo $(\mathrm{P})$ de dietas, com e sem a suplementação de fitase, por suínos machos castrados com 20,42 $\pm 2,45 \mathrm{~kg}$ de peso vivo, pelo método da coleta total de excretas. No segundo experimento foram avaliados o desempenho zootécnico, a deposição de minerais nos $3^{\circ}$ e $4^{\circ}$ metacarpos, a produção e a composição das fezes de fêmeas suínas nas fases de crescimento e de terminação, alimentadas com as seguintes dietas experimentais: Controle Positivo (CP) - formulada para atender as exigências nutricionais de suínos em

\footnotetext{
${ }^{1}$ Zootecnistas, Universidade Estadual Paulista “Júlio de Mesquita Filho”, UNESP, Jaboticabal, SP, Brasil. E-mail: hgfaria@ yahoo.com.br; educazoo4@yahoo.com.br

2 Prof $^{\mathrm{a}}$ Dr $^{\mathrm{a}}$, UNESP, Jaboticabal, SP, Brasil. E-mail: thomaz@fcav.unesp.br

3 Prof. Dr., Universidade de São Paulo, USP, Piracicaba, SP, Brasil. E-mail: usruiz@usp.br

${ }^{4}$ Prof. Dr., Universidad Nacional Agraria de La Selva, Tingo Maria, Peru. E-mail: rizalcides@gmail.com

5 Prof. Dr., Universidade Federal do Ceará, UFC, Fortaleza, CE, Brasil. E-mail: pedro_watanabe@yahoo.com.br

${ }^{6}$ Prof. Dr., Universidade Camilo Castelo Branco, UNICASTELO, Descalvado, SP, Brasil. E-mail: gmpmelo@terra.com.br

* Author for correspondence
} 
crescimento e em terminação; Controle Negativo (CN) - CP com os níveis de Ca e $\mathrm{P}$ atendidos em 84\% e $65 \%$, respectivamente; Controle Negativo + Fitase $(\mathrm{CN}+\mathrm{F})$ - dieta $\mathrm{CN}+0,01 \%$ de fitase $(500 \mathrm{FTU} /$ $\mathrm{kg}$ ). A adição da enzima melhorou os coeficientes de disponibilidade do $\mathrm{P}$ e do $\mathrm{Ca}$ em $14,34 \%$ e em $4,08 \%$, respectivamente em relação à dieta sem fitase. No segundo experimento, a deposição de zinco nos metacarpos foi aumentada pela enzima e as excreções fecais de $\mathrm{Ca}, \mathrm{P}$ e Cobre foram diminuídas pelo uso da enzima nos animais PHY em relação aos animais PC. A adição de fitase melhorou o aproveitamento do fósforo fítico e do cálcio pelos suínos, sendo recomendada como uma das formas de se reduzir o impacto ambiental causado pela suinocultura.

Palavras-chave: Cálcio, enzima, fósforo, leitões, poluição ambiental

\section{Introduction}

From $60 \%$ to $80 \%$ of vegetable phosphorous (P) is attached to the phytate molecule (myoinositol hexaphosphate ester), being unavailable for monogastric animals (SELLE; RAVINDRAN, 2008; DERSJANT-LI et al., 2015). Thus, it is necessary to supplement the diets of these animals with a source of available $P$. This represents an economical problem because of the expense of $\mathrm{P}$ supplementation as well as environmental concerns. The excess $\mathrm{P}$, which is unavailable to the animals, is excreted and can pollute the environment.

The problem is that in the small intestine lumen of monogastric animals, which presents a $\mathrm{pH}$ close to neutral, phytate is poorly soluble (SCHLEMMER et al., 2001). This causes phytate to be unavailable to the endogenous phytase in pigs, the enzyme necessary to degrade the phytate and release P. Furthermore, phytate presents highly ionized orthophosphate groups that can form complexes with a variety of cations, such as calcium (Ca), iron $(\mathrm{Fe})$, copper $(\mathrm{Cu})$ and zinc (Zn) (WOYENGO et al. 2009), the amino group of some amino acids (lysine, arginine and histidine) and conjugated glucose molecules, making them unavailable by the formation of insoluble complexes in the digestive tract (PETER et al., 2009; SCHLEGEL et al., 2009). Thus, phytate is considered an antinutritional factor, affecting not only phosphorous availability but also the availability of cations, amino acids and energy (SELLE; RAVINDRAN, 2008; DERSJANT-LI et al., 2015).

The inclusion of exogenous phytases in swine feeding can improve the utilization of phytate $\mathrm{P}$ by degrading this molecule in the stomach of the animals. The low $\mathrm{pH}$ of the stomach makes phytate more soluble, allowing the action of phytases. Thus, the majority of $\mathrm{P}$ that was attached to phytate can be released to the animal in their small intestine, where this mineral can be absorbed (ADEOLA; COWIESON, 2011).

The use of this enzyme may promote a better use of vegetable $P$, which may be reflected in a reduction of the inclusion of $\mathrm{P}$ sources in the diets. In this way, $\mathrm{P}$ excretion in feces can be reduced and some minerals and amino acids can be more available to the animal. However, the responses of phytase addition to the diets depend on the diet composition, level and source of phytase and $\mathrm{P}$ and Ca diet concentrations (DERSJANT-LI et al., 2015).

The objectives in this study were to evaluate, in two trials, the phytase enzyme in diets composed mainly of corn, rice and soybean meal in swine feeding. In the first trial, energy and protein digestibilities and $\mathrm{Ca}$ and $\mathrm{P}$ availabilities in the diets of pigs were evaluated. In the second trial, performance, bone mineral depositions and mineral excretions in feces of growing and finishing swine were evaluated.

\section{Material and Methods}

The animal procedures were reviewed and approved by the Universidade Estadual Paulista Committee of Ethics and Animal Welfare (protocol $\mathrm{n}^{\circ}$ 005101/11) and followed guidelines established by the Brazilian Council of Animal Experimentation. The trials were performed at the 
Sector of Swine Production in the Animal Science Department at Universidade Estadual Paulista, Campus of Jaboticabal. In the digestibility trial, the total feces and feed collection method was employed and 16 Topigs barrows (Topigs 20 sow $\mathrm{x}$ Toppi boar, $20.42 \pm 2.25 \mathrm{~kg}$ ) were placed in metabolic cages. The animals were allotted into two diets, composed mainly of corn, rice and soybean meal, which differed only in phytase addition. The control diet (C) had no phytase and the other diet (PHY) was supplemented with $0.01 \%$ phytase $(500$ $\mathrm{FTU} / \mathrm{kg}$ of ration). The diets were formulated with reductions of $2.85 \%, 2.63 \%$ and $20 \%$ in the levels of digestible energy, crude protein and available $\mathrm{P}$, respectively, in relation to Rostagno et al. (2005) recommendations (Table 1).

Table 1. Centesimal and nutritional compositions of diets used in trial 1.

\begin{tabular}{|c|c|}
\hline Ingredients $(\%)$ & Control - Phytase \\
\hline Corn & 64.535 \\
\hline Soybean meal, $45 \%$ & 26.667 \\
\hline Rice meal & 5.000 \\
\hline Dicalcium phosphate & 1.235 \\
\hline Limestone & 1.077 \\
\hline Salt & 0.353 \\
\hline L-Lysine $\mathrm{HCl}, 78 \%$ & 0.184 \\
\hline DL- Metionine, 99\% & 0.020 \\
\hline Mineral supplement ${ }^{1}$ & 0.300 \\
\hline Vitamin supplement ${ }^{2}$ & 0.300 \\
\hline Amoxicilin ${ }^{3}$ & 0.030 \\
\hline Leucomicin $^{4}$ & 0.030 \\
\hline Inert / Phytase ${ }^{5}$ & 0.269 \\
\hline Total & 100.000 \\
\hline \multicolumn{2}{|l|}{ Calculated composition } \\
\hline Digestible energy $(\mathrm{kcal} / \mathrm{kg})$ & 3303 \\
\hline Crude protein $(\%)$ & 18.5 \\
\hline Total lysine (\%) & 1.1 \\
\hline Total methionine + cystine $(\%)$ & 0.62 \\
\hline Calcium $(\%)$ & 0.83 \\
\hline Available phosphorous (\%) & 0.34 \\
\hline
\end{tabular}

${ }^{1}$ Mineral supplement, provided per kilogram of diet: $\mathrm{Fe}-120 \mathrm{mg}, \mathrm{Cu}-105 \mathrm{mg}, \mathrm{Mn}-60 \mathrm{mg}, \mathrm{Zn}-120 \mathrm{mg}, \mathrm{Co}-1.08 \mathrm{mg}, \mathrm{I}-2.52$ mg, Se - 0.36 mg; ${ }^{2}$ Vitamin supplement, provided per kilogram of diet: Vit. A - 9000 UI, Vit. D3 - 1500 UI, Vit. E - 22.5 mg, Vit. K3 - $3.75 \mathrm{mg}$, Vit. B12 - $21 \mathrm{mcg}$, Vit. B2 - $6.9 \mathrm{mg}$, Biotin - $0.15 \mathrm{mg}$, Ca panthotenate- $9 \mathrm{mg}$, Niacin - $30 \mathrm{mg}$, Coline - $0.225 \mathrm{~g}$, Growth promoter - $0.15 \mathrm{~g}$, Antioxidant $-0.075 \mathrm{~g} ;{ }^{3}$ Biomox -50 of amoxicilin per $100 \mathrm{~g}$ of product; ${ }^{4}$ Leucomag $-30 \mathrm{~g}$ of leucomicin per $100 \mathrm{~g}$ of product; ${ }^{5}$ In diet $\mathrm{P}$, phytase inclusion was $0.01 \%$, substituting inert.

The animals were housed in the metabolic cages for ten days. The first five days provided an adaptation period to the cages and diets and were used to measure individual feed consumption. In the last five days, the feces and rations samples were collected for chemical analyses. The feed quantities offered to each animal during the collection period were the product of the measured consumption coefficient (quantities of rations consumed during the adaptation period by each animal divided by the metabolic weight of the animal, which presented the lowest ration consumption) and the metabolic 
weight of each animal. These quantities were offered to assure full consumption of the rations by the animals, avoiding feed refusals. The feeds were offered twice a day, at 8:00 $\mathrm{h}$ and 17:00 h, and the rations were previously weighted and then mixed with water $(1: 1, \mathrm{w}: \mathrm{v})$. Drinking water access was ad libitum. Ferric oxide was used as a fecal marker to determine the beginning and the end of the collection period. The feces were collected and weighed twice a day and then frozen.

In trial two, performance, feces and mineral excretion in feces, bone mineral depositions and contents were evaluated using 27 Topigs gilts (Topigs 20 sow x Toppi boar, $37.7 \pm 5.3 \mathrm{~kg}$ of initial body weight) allotted into three diets (Table
2): Positive control (PC) - basal diet formulated to achieve nutrient requirements of growing and finishing gilts according to Rostagno et al. (2005); Negative control (NC) - PC with reduced levels of $\mathrm{Ca}$ and $\mathrm{P}$, achieving these mineral requirements in $84 \%$ and $65 \%$, respectively; Negative control with phytase (PHY) - diet NC supplemented with $0.01 \%$ phytase (500 FTU/kg of ration). This trial was divided in three phases: I, from 75 to 92 days of age; II, from 93 to 113 days of age; III, from 114 to 158 days of age. In the beginning of each phase, the animals were weighed and the diets were changed according to their nutritional requirements. The animals were housed individually in $2.55 \mathrm{~m}^{2}$ pens, with semi automated feeders and free access to drinking water.

Table 2. Centesimal and nutritional compositions of diets used in phases I, II and III of trial two.

\begin{tabular}{lccccccccc}
\hline \multirow{2}{*}{ Ingredients (\%) } & \multicolumn{3}{c}{ Phase I } & \multicolumn{3}{c}{ Phase II } & \multicolumn{3}{c}{ Phase III } \\
\cline { 2 - 10 } & $\mathrm{PC}^{*}$ & $\mathrm{NC}^{*}$ & $\mathrm{PHY}^{*}$ & $\mathrm{PC}^{*}$ & $\mathrm{NC}^{*}$ & $\mathrm{PHY}$ & $\mathrm{PC}$ & $\mathrm{NC}$ & $\mathrm{PHY}^{*}$ \\
\hline Corn & 65.49 & 67.31 & 67.31 & 69.48 & 71.31 & 71.30 & 75.10 & 76.89 & 76.89 \\
Soybean meal, 45\% & 20.42 & 19.61 & 19.61 & 16.85 & 16.04 & 16.04 & 11.88 & 11.10 & 11.10 \\
Rice meal & 10.00 & 10.00 & 10.00 & 10.00 & 10.00 & 10.00 & 10.00 & 10.00 & 10.00 \\
Soybean oil & 1.31 & 0.76 & 0.76 & 1.11 & 0.56 & 0.56 & 0.76 & 0.21 & 0.21 \\
Dicalcium phosphate & 1.13 & 0.51 & 0.51 & 0.88 & 0.26 & 0.26 & 0.72 & 0.10 & 0.10 \\
Limestone & 0.66 & 0.81 & 0.81 & 0.64 & 0.79 & 0.79 & 0.61 & 0.75 & 0.75 \\
Salt & 0.36 & 0.36 & 0.36 & 0.34 & 0.34 & 0.34 & 0.32 & 0.32 & 0.32 \\
Mineral and vitamin supplement ${ }^{1}$ & 0.10 & 0.10 & 0.10 & 0.30 & 0.30 & 0.30 & 0.30 & 0.30 & 0.30 \\
Inert / Phytase & 0.10 & 0.11 & 0.10 & 0.10 & 0.10 & 0.10 & 0.10 & 0.10 & 0.10 \\
L-Lysine HCl, 78\% & 0.30 & 0.31 & 0.31 & 0.25 & 0.26 & 0.26 & 0.19 & 0.21 & 0.21 \\
L-Threonine, 98\% & 0.08 & 0.08 & 0.08 & 0.04 & 0.04 & 0.04 & 0.01 & 0.01 & 0.01 \\
DL- Methionine, 99\% & 0.05 & 0.05 & 0.05 & 0.01 & 0.01 & 0.01 & 0.01 & - & - \\
Total & 100.0 & 100.0 & 100.0 & 100.0 & 100.0 & 100.0 & 100.0 & 100.0 & 100.0 \\
\hline Calculated values & & & & & & & & & \\
\hline Metabolizable energy (kcal/ kg) & 3230 & 3220 & 3220 & 3230 & 3220 & 3220 & 3230 & 3220 & 3220 \\
Crude protein (\%) & 16.6 & 16.4 & 16.4 & 15.2 & 15.0 & 15.0 & 13.4 & 13.2 & 13.2 \\
Total lysine (\%) & 1.02 & 1.01 & 1.01 & 0.89 & 0.87 & 0.89 & 0.73 & 0.72 & 0.72 \\
Total methionine (\%) & 0.32 & 0.32 & 0.32 & 0.26 & 0.26 & 0.26 & 0.23 & 0.23 & 0.23 \\
Total threonine (\%) & 0.70 & 0.70 & 0.70 & 0.63 & 0.61 & 0.61 & 0.52 & 0.52 & 0.52 \\
Calcium (\%) & 0.63 & 0.53 & 0.53 & 0.55 & 0.45 & 0.45 & 0.48 & 0.38 & 0.38 \\
Available phosphorous (\%) & 0.33 & 0.22 & 0.22 & 0.28 & 0.17 & 0.17 & 0.25 & 0.13 & 0.13 \\
\hline
\end{tabular}

*PC - positive control; NC - negative control; PHY - negative control + phytase. ${ }^{1}$ FRIMIX ${ }^{\circledR}$ - Fri-Ribe, did not contain growth promoters. Provided per kilogram of diet: Vit A - 4000 U.I.; Vit. D3 - 220 U.I.; Vit. E - 22 mg; Vit. K - 0.5 mg; Vit. B2 - 3.75 mg; Vit B12 - $25 \mu \mathrm{g}$; Calcium panthotenate - $12 \mathrm{mg}$; Niacin - 20 mg; Coline - 60 mg; Iodine - $140 \mu$ g; Selenium - $300 \mu g$; Manganese - $10 \mathrm{mg}$; Zinc - $100 \mathrm{mg}$; Copper - $10 \mathrm{mg}$; Iron - $99 \mathrm{mg}$. ${ }^{2}$ Phytase inclusion was $0.01 \%$, substituting inert. 
The determinations of average daily gain (ADG), average daily feed intake (ADFI) and the calculation of feed conversion ratio (FCR) were performed by weighing the animals, as well as the offered feed and the wasted feed in the feeders at the beginning and end of each phase. The wasted feed was collected daily, quantified and discounted from the total amount offered to the animals.

The evaluation of feces production, $\mathrm{P}, \mathrm{Ca}$, magnesium $(\mathrm{Mg}), \mathrm{Zn}$, copper $(\mathrm{Cu})$ and manganese (Mn) excretions were performed by collecting feces during the finishing phase, as follows: twice a week pens were washed with pressurized water and from the end of the washing until 24 hours later all the feces produced by the animals were collected. The pens were separated by wood panels to avoid the ability of one animal to defecate in the pen of another through the bars between the pens. Parts of the feces were collected by grab sampling, directly from the rectum of the animals, and the others parts were collected from the floor. The feces samples collected from the floor of the pens were weighed and disposed of, and the feces samples collected from the rectum of the animals were weighed and frozen for laboratory analyses.

At the end of the collection period, in both trials, the feces of each animal were thawed, homogenized and sampled. The feces portions were initially dried in a forced draft oven at $55^{\circ} \mathrm{C}$ for 72 hours and subsequently ground in a knife mill to pass through a $1 \mathrm{~mm}$ screen; the ration samples were only ground.

In the processed feces and feed samples of trial one the following laboratory analyses were performed: dry matter (DM), crude protein $(\mathrm{CP})$ and gross energy (GE) in a adiabatic bomb calorimeter, $\mathrm{P}$ by calorimetry and $\mathrm{Ca}$ using atomic absorption spectrophotometry, according to Silva and Queiróz (2002). The same analyses were performed in the samples of trial two, plus the determinations of $\mathrm{Mg}, \mathrm{Zn}, \mathrm{Cu}$ and $\mathrm{Mn}$ using atomic absorption spectrophotometry, according to Silva and Queiróz (2002). All determinations were conducted at the
Biochemistry lab of Technology Department, and at the Animal Nutrition Lab of the Animal Science Department, both in FCAV - Unesp, Jaboticabal Campus.

In trial one, the $\mathrm{DM}, \mathrm{CP}, \mathrm{GE}, \mathrm{Ca}$ and $\mathrm{P}$ values were used to calculate $\mathrm{CP}$ and GE digestibilities, $\mathrm{Ca}$ and $\mathrm{P}$ availabilities and their respective digestible and available values, according to Adeola (2001). In trial two, considering the quantification of feces excretions, the contents of DM and minerals in feces and feeds and the animal feed consumption, the amounts of macro- and micro minerals excreted per kilogram of ingested feed (AMEIF) were calculated dividing the amount of mineral excreted per day per animal (g for $\mathrm{Ca}, \mathrm{P}$ and $\mathrm{Mg}$, or $\mathrm{mg}$ for $\mathrm{Cu}, \mathrm{Fe}, \mathrm{Mn}$ and $\mathrm{Zn}$ ) by the amount of mineral ingested per day per animal (g).

At the end of the trial, all the animals were slaughtered in a commercial slaughter house and the 3rd and 4th metacarpals of each pig were removed, identified and frozen for further DM, mineral matter (MM) and mineral determinations. The samples were thawed and autoclaved at $120^{\circ}$ $\mathrm{C}$ in one atmosphere for 10 minutes to facilitate soft tissue withdrawal. After this procedure, the samples were dried in a forced draft oven at 65 ${ }^{\circ} \mathrm{C}$ for 72 hours and then each bone was broken horizontally to allow for easier fat extraction. Fat extraction was performed in a Soxhlet extractor with petroleum ether for six hours. Sequentially, the bones were ground in a ball mill and submitted to defatted DM and MM determinations and digestion with $6 \mathrm{~N}$ hydrochloric acid. In the digested samples, the extract determinations of $\mathrm{Ca}, \mathrm{Mg}$, $\mathrm{Cu}, \mathrm{Fe}, \mathrm{Mn}$ and $\mathrm{Zn}$ were analyzed using atomic absorption spectrophotometry; $\mathrm{P}$ was analyzed using colorimetry.

In both trials a complete randomized block design was employed, to control the initial weight differences, with eight repetitions per diet in trial one and nine in trial two, each animal was considered an experimental unit. All data were 
submitted to analysis of variance, using the General Linear Models of SAS (SAS 9.1, SAS Institute, Cary, NC, USA). In trial two means were separated by the Student - Newman - Keuls (SNK) test at $5 \%$ probability. The performance evaluations were accomplished in periods because the animals were not redistributed in the original blocks after the end of each phase. The periods were: Period I - 75 to 92 days of age, Period II - 75 to 113 days of age and Period III - 75 to 158 days of age.

\section{Results and Discussion}

Phytase addition improved $(\mathrm{P}<0.05) \mathrm{P}$ and $\mathrm{Ca}$ diet availabilities for the pigs by $14.34 \%$ and $4.08 \%$, respectively, compared with that observed in the diet without the enzyme (Table 3). The enzyme inclusion in the pigs diet improved the utilization of phytate $\mathrm{P}$ by degrading this molecule and therefore making part of the $\mathrm{P}$ available. In addition, part of the Ca complexed by the phytate molecule was liberated and available for the animals.

Table 3. Nutrient digestibilities and digestible nutrients of diets with reduced digestible energy, crude protein, Ca and P levels, supplemented or not with phytase, for young pigs.

\begin{tabular}{lccc}
\hline Item & Control diet & Phytase diet & SEM $^{2}$ \\
\hline Gross energy digestibility (\%) & 85.11 & 84.78 & 0.34 \\
Digestible energy (kcal kg-1) $^{-1}$ & 3758.44 & 3725.97 & 15.69 \\
Crude protein digestibility (\%) $^{\text {Digestible protein (\%) }}$ & 84.16 & 84.36 & 0.49 \\
Calcium availability (\%) $^{1}$ & 18.54 & 18.59 & 0.17 \\
Available calcium (\%) $^{1}$ & 79.20 & 82.44 & 0.85 \\
Phosphorous availability (\%) $^{1}$ & 0.79 & 0.87 & 0.01 \\
Available phosphorous (\%) $^{1}$ & 56.29 & 64.36 & 1.71 \\
\hline
\end{tabular}

${ }^{1} P<0.05$.

${ }^{2}$ Standard error of the means.

These results confirms the efficacy of phytase in improving $\mathrm{P}$ and $\mathrm{Ca}$ availabilities and are in accordance with the findings of several researchers (KIM et al., 2005; BRAÑA et al., 2006; KIES et al., 2006; NYACHOTI et al., 2006; GUGGENBUHL et al., 2007; HTOO et al., 2007; POULSEN et al., 2007; MOEHN et al., 2007; SANDS; KAY, 2007; KIM et al., 2008; POMAR et al., 2008; HILL et al., 2009; POULSEN et al., 2010a, 2010b; ATAKORA et al., 2011; ALMEIDA et al., 2013; MADRID et al., 2013; FÁVERO et al., 2014; RUTHERFURD et al., 2014; KAHINDI et al., 2015) who verified improvements of $\mathrm{P}$ availability from $4.1 \%$ to greater than $100 \%$ with phytase addition in pig diets. This great range in $\mathrm{P}$ availability improvement is a consequence of differences in the design of the mentioned studies, such as the use of different feed ingredients, different phytase levels or activities, use of other enzymes in combination with phytase and diets with different nutrient levels.

However, some studies reported no positive effects of phytase addition in pig diets over $\mathrm{Ca}$ availability (MOEHN et al., 2007; POMAR et al., 2008; ATAKORA et al., 2011), which may be related to differences in diet compositions, resulting in a greater or lower association between phytic acid and $\mathrm{Ca}$ and to the type of phytase used (DERSJANT-LI et al., 2015). By contrast, the improvement in Ca availability found in this study is in accordance with the results found in many studies (BRAÑA et al., 2006; GUGGENBUHL et 
al., 2007; KIES et al., 2006; KIM et al., 2005, 2008; POULSEN et al., 2010a; SANDS; KAY, 2007; ALMEIDA et al., 2013; MADRID et al., 2013; FÁVERO et al., 2014; RUTHERFURD et al., 2014; KAHINDI et al., 2015), which show that phytase can effectively improve not only $\mathrm{P}$ availability but also $\mathrm{Ca}$ availability.

There was no difference $(\mathrm{P}>0.05)$ for $\mathrm{GE}$ and $\mathrm{CP}$ digestibilities in the diets with or without phytase. Complexes formed by phytate - protein or phytate - conjugated glucose molecules might be broken by phytase, allowing greater amino acid and energy use by the animals, respectively. Nevertheless, phytase inclusion did not improve protein and energy digestibility possibly because of the low complexation between these nutrient and phytate in the feedstuffs used. Phytic acid protein and carbohydrates associations may not be strong enough to depress CP or energy digestibility
(ORYSCHAK et al., 2002). The results found in the present research are in agreement with the ones found by Kim et al. (2005, 2008); Madrid et al. (2013); Fávero et al. (2014); and Kahindi et al. (2015) for protein digestibility, and Oryschak et al. (2002); Kim et al. (2005); Nortey et al. (2007); Kim et al. (2008); Atakora et al. (2011); and Kahindi et al. (2015) for energy digestibility.

In trial 2, the performance parameters evaluated were affected by the experimental diets in period III (Table 4). The pigs fed the NC diet presented a lower $(\mathrm{P}<0.05)$ feed conversion ratio than the animals submitted to the PC diet, and both presented similar $(\mathrm{P}>0.05) \mathrm{FCR}$ in comparison with the PHY animals. The $8.6 \%$ difference higher ADFI $(\mathrm{P}>0.05)$ by the NC animals, as compared to PC pigs, did not promote a greater ADG, which led, therefore, to a $7 \%$ decrease $(\mathrm{P}<0.05)$ in the FCR of the $\mathrm{NC}$ animals compared to the PC animals.

Table 4. Performance of gilts, in periods 1 (75 - 92 days of age), 2 (75 - 113 days of age) and 3 (75 - 158 days of age), fed diets with different $\mathrm{P}$ and $\mathrm{Ca}$ levels, with or without phytase.

\begin{tabular}{lccccc}
\hline \multicolumn{1}{c}{ Item } & Periods & PC & NC & PHY $^{*}$ & SEM $^{2}$ \\
\hline \multirow{3}{*}{ Average daily feed intake $(\mathrm{kg})$} & I & 2.30 & 2.39 & 2.30 & 0.05 \\
& II & 2.29 & 2.41 & 2.27 & 0.05 \\
& III & 2.32 & 2.52 & 2.40 & 0.06 \\
Average daily gain $(\mathrm{kg})$ & I & 0.96 & 0.99 & 0.95 & 0.01 \\
& II & 0.93 & 0.93 & 0.88 & 0.02 \\
Feed conversion ratio & III & 1.08 & 1.09 & 1.07 & 0.02 \\
& I & 2.40 & 2.41 & 2.41 & 0.04 \\
& II & 2.46 & 2.60 & 2.58 & 0.04 \\
\hline
\end{tabular}

*PC - positive control; NC - negative control; PHY - negative control + phytase.

${ }^{1}$ Within a row means without a common superscript differ $(p<0.05)$ by Student - Newman - Keuls test.

${ }^{2}$ Standard error of the means.

Despite the lack of effects of the feed enzyme over ADG and ADFI of the pigs, it is possible to note the beneficial effect of phytase, as it was able to provide similar feed conversions between the PC and PHY animals in Period III. As the PHY diet had less $\mathrm{P}, \mathrm{Ca}$, metabolizable energy and crude protein contents than the PC diet, it is possible to affirm that phytase supplementation permitted a better use of 
the diet nutrients by the animals. The results found in this study are similar to the results verified by Braña et al. (2006); Kies et al. (2006); and Sands and Kay (2007), who did not observe differences in the performance of pigs fed a control diet, which met the $\mathrm{P}$ and $\mathrm{Ca}$ requirements of the animals, or a diet with reduced contents of these minerals that was supplemented with phytase (500 FTU). Atakora et al. (2011) fed growing gilts diets with reduced $\mathrm{P}$ and crude protein levels or a control diet that met the animal's requirements and also found no differences in pig performance. In contrast, Santos et al. (2014) verified improvements in ADG and in feed efficiency of pigs fed diet with reduced nutrient levels but supplemented with 2000 FTU/kg of feed, in comparison with animals submitted to a diet without nutrient restriction. But it is important to note that, in this case, phytase activity in diets was much higher than the employed in the present study.

The animals fed the PC diet excreted greater quantities $(\mathrm{P}<0.05)$ of $\mathrm{Ca}, \mathrm{P}$ and $\mathrm{Cu}$ than the $\mathrm{PHY}$ pigs, which did not differ $(\mathrm{P}>0.05)$ from the $\mathrm{NC}$ animals (Table 5). However, the PHY animals excreted 18\%, 23.1\% and $12.09 \%$ less $\mathrm{Ca}, \mathrm{P}$, and $\mathrm{Cu}$, respectively, than the $\mathrm{NC}$ animals, indicating that the phytase made these minerals available from the feed ingredients, resulting in lower excretion of the minerals in feces and reducing its pollutant impact. Htoo et al. (2007) and Atakora et al. (2011) also verified reduction in P excretion in pig feces when the animals were fed diets with reduced $\mathrm{P}$ levels, supplemented with phytase, in comparison with animals submitted to a diet that met $\mathrm{P}$ requirements, with no supplemented phytase. Madrid et al. (2013) also observed improvements in $\mathrm{P}$ and $\mathrm{Cu}$ digestibilities in diet supplemented with phytase (500 FTU/kg) in comparison to diet with no phytase for pigs, and calculated that the reductions in $\mathrm{P}$ and $\mathrm{Cu}$ excretions, because of phytase, would be of $39 \%$ and $33 \%$, respectively.

The amount of daily produced feces and the quantities of $\mathrm{Mg}, \mathrm{Mn}$ and $\mathrm{Zn}$ excreted were similar $(\mathrm{P}>0.05)$ between the animals of the three treatments, differing from the findings of Zhang et al. (2003), who fed pigs a multi-enzyme preparation, supplying 500U of $\beta$-glucanase and 300 FTU phytase per kilogram of diet, and verified a reduction in dry and wet feces excretion, in comparison with pigs fed diets with no enzyme. By contrast, Nyachoti et al. (2006) did not find reductions in the feces excretion of pigs fed diets supplemented with enzymes.

The majority of mineral and ash contents and the weight of the third and fourth metacarpals of the pigs (Tab. 5) were not affected $(\mathrm{P}>0.05)$ by the diets. Zinc was the exception, and the zinc content was higher $(\mathrm{P}<0.05)$ in the bones of the animals fed with diet PHY. Diet effects on mineral bone contents are dependent on dietary mineral contents and on the magnitude of mineral reductions in the diets. In this study, the reductions of $18 \%$ and $16 \%$ in available $\mathrm{P}$ and $\mathrm{Ca}$ contents, respectively, in $\mathrm{NC}$ and in $\mathrm{PHY}$ diets did not promote significant effects in bone mineral content. The animals fed diet NC had a numerically greater ADFI, which most likely compensated the lower available $\mathrm{P}$ and $\mathrm{Ca}$ in the diet. 
Table 5. Minerals excreted per kilogram of ingested feed, daily feces production and minerals, ash and dry weight bone contents of finishing gilts, fed diets with different $\mathrm{P}$ and $\mathrm{Ca}$ levels, with or without phytase.

\begin{tabular}{|c|c|c|c|c|}
\hline Item & $\mathrm{PC}^{*}$ & $\mathrm{NC}^{*}$ & $\mathrm{PHY}^{*}$ & $\mathrm{SEM}^{2}$ \\
\hline \multicolumn{5}{|c|}{ Minerals excreted per kilogram of ingested feed } \\
\hline Calcium $\left(\mathrm{g} \mathrm{g}^{-1}\right)$ & $0.54^{\mathrm{a}}$ & $0.50^{\mathrm{ab}}$ & $0.41^{\mathrm{b}}$ & 0.02 \\
\hline Phosphorous $\left(\mathrm{g} \mathrm{g}^{-1}\right)$ & $0.66^{\mathrm{a}}$ & $0.52^{\mathrm{ab}}$ & $0.40^{\mathrm{b}}$ & 0.03 \\
\hline Magnesium $\left(\mathrm{g} \mathrm{g}^{-1}\right)$ & 0.76 & 0.71 & 0.75 & 0.03 \\
\hline Copper $\left(\mathrm{mg} \mathrm{g}^{-1}\right)$ & $1.11^{\mathrm{a} 1}$ & $1.02^{\mathrm{ab}}$ & $0.91^{\mathrm{b}}$ & 0.04 \\
\hline Manganese $\left(\mathrm{mg} \mathrm{g}^{-1}\right)$ & 0.63 & 0.68 & 0.70 & 0.02 \\
\hline Zinc $\left(\mathrm{mg} \mathrm{g}^{-1}\right)$ & 0.64 & 0.59 & 0.60 & 0.03 \\
\hline Daily feces production $(\mathrm{g})$ & 0.87 & 0.93 & 0.91 & 0.04 \\
\hline \multicolumn{5}{|l|}{ Minerals bone contents } \\
\hline Calcium $(\%)$ & 24.71 & 26.01 & 26.35 & 0.5 \\
\hline Phosphorous (\%) & 11.22 & 11.64 & 11.63 & 0.24 \\
\hline Magnesium (\%) & 4.22 & 4.09 & 4.30 & 0.07 \\
\hline Copper (ppm) & 3.62 & 3.38 & 3.41 & 0.08 \\
\hline Iron (ppm) & 33.46 & 32.53 & 28.19 & 1.16 \\
\hline Manganese (ppm) & 2.96 & 3.01 & 2.88 & 0.08 \\
\hline Zinc (ppm) & $96.63^{\mathrm{b} 1}$ & $106.78^{b}$ & $119.94^{\mathrm{a}}$ & 3.29 \\
\hline Bone Ash (\%) & 56.18 & 57.20 & 59.50 & 1.25 \\
\hline Bone dried weight (g) & 22.75 & 19.42 & 21.12 & 0.58 \\
\hline
\end{tabular}

*PC - positive control; NC - negative control; PHY - negative control + phytase.

${ }^{1}$ Within a row means without a common superscript differ $(\mathrm{P}<0.05)$ by Student - Newman - Keuls test.

${ }^{2}$ Standard error of the means.

Shelton et al. (2004) did not verify differences in bone ash, $\mathrm{Ca}, \mathrm{P}, \mathrm{Fe}$ and $\mathrm{Mg}$ of pigs fed a control diet, without $\mathrm{Ca}$ and $\mathrm{P}$ reductions and phytase, or a diet with reductions of $42 \%$ and $17 \%$ in $\mathrm{P}$ and $\mathrm{Ca}$ contents, respectively, supplemented with phytase. Similarly, Hinson et al. (2009) and Madrid et al. (2013) did not find differences in swine bone parameters, such as $\mathrm{Ca}, \mathrm{P}$ and ash contents, by phytase supplementation in the diets, with reduction in available $\mathrm{P}$ content. By contrast, Lüdke et al. (2002) verified decreases in metacarpal weight, ash content, $\mathrm{Ca}$ and $\mathrm{P}$ deposition in metacarpals of pigs fed diets with a $58 \%$ reduction in available $\mathrm{P}$ and a $32 \%$ reduction in Ca, supplemented with 750 FTU phytase, in comparison with animals fed a diet without $\mathrm{P}$ and $\mathrm{Ca}$ reductions and with no phytase. In the research of Ludke et al. (2002) it is important to consider that the reductions in $\mathrm{P}$ and $\mathrm{Ca}$ contents in diets were much greater than the ones used in the present research, which can explain the difference in the results.

\section{Conclusions}

Phytase addition to pig diets is recommended as a method to improve $\mathrm{P}$ and $\mathrm{Ca}$ availabilities for pigs and reduce the environmental impact that may be caused by pig production without interfering with animal performance.

\section{References}

ADEOLA, O. Digestion and balance techniques in pigs. In: LEWIS, A. J.; SOUTHERN, L. L. (Ed.). Swine nutrition. $2^{\text {th }}$ ed. Boca Raton: CRC Press, 2001. p. 903916. 
ADEOLA, O.; COWIESON, A. J. Opportunities and challenges in using exogenous enzymes to improve nonruminant animal production. Journal of Animal Science, Champaign, v. 89, n. 10, p. 3189-3218, 2011.

ALMEIDA, F. N.; SULABO, R. C.; STEIN, H. H. Effects of a novel bacterial phytase expressed in Aspergillus Oryzae on digestibility of calcium and phosphorus in diets fed to weanling or growing pigs. Journal of Animal Science and Biotechnology, London, v. 4, n. 8, p. 1-10, 2013. Available at: <http://www.jasbsci.com/ content/4/1/8>. Acessed at: 6 jul. 2015.

ATAKORA, J. K. A.; MOEHN, S.; SANDS, J. S.; BALL, R. O. Effects of dietary crude protein and phytasexylanase supplementation of wheat grain based diets on energy metabolism and enteric methane in growing finishing pigs. Animal Feed Science and Technology, Amsterdam, v. 166-167, p. 422-429, 2011. Special Issue.

BRAÑA, D. V.; ELLIS, M.; CASTAÑEDA, E. O.; SANDS, J. S.; BAKER, D. H. Effect of a novel phytase on growth performance, bone ash, and mineral digestibility in nursery and grower-finisher pigs. Journal of Animal Science, Champaign, v. 84, n. 7, p. 1839-1849, 2006.

DERSJANT-LI, Y.; AWATI, A.; SCHULZE, H.; PARTRIDGE, G. Phytase in non-ruminant animal nutrition: a critical review on phytase activities in the gastrointestinal tract and influencing factors. Journal of the Science of Food and Agriculture, London, v. 95, n. 5, p. 878-896, 2015.

FÁVERO, A.; RAGLAND, D.; VIEIRA, S. L.; OWUSUASIEDU, A.; ADEOLA, O. Digestibility marker and ileal amino acid digestibility in phytase-supplemented soybean or canola meals for growing pigs. Journal of Animal Science, Champaign, v. 92, n. 12, p. 5583-5592, 2014.

GUGGENBUHL, P.; PIÑÓN QUINTANA, A.; SIMÕES NUNES, C. Comparative effects of three phytases on phosphorous and calcium digestibility in the growing pig. Livestock Science, Amsterdam, v. 109, n. 1-3, p. 258260, 2007.

HILL, B. E.; SUTTON, A. L.; RICHERT, B. T. Effects of low-phytic acid soybean meal, and phytase on nutrient digestibility and excretion in growing pigs. Journal of Animal Science, Champaign, v. 87, n. 4, p. 1518-1527, 2009.

HINSON, R. B.; SCHINCKEL, A. P.; RADCLIFFE, J. S.; ALLEE, G. L.; SUTTON, A. L.; RICHERT, B. T. Effect of feeding reduced crude protein and phosphorous diets on weaning-finishing pig growth performance, carcass characteristics, and bone characteristics. Journal of Animal Science, Champaign, v. 87, n. 4, p. 1502-1517, 2009.
HTOO, J. K.; SAUER, W. C.; YAÑEZ, J. L.; CERVANTES, M.; ZHANG, J. H.; HELM, J. H.; ZIJLSTRA, R. T. Effect of low-phytate barley or phytase supplementation to a barley-soybean meal diet on phosphorous retention and excretion by grower pigs. Journal of Animal Science, Champaign, v. 85, n. 11, p. 2941-2948, 2007.

KAHINDI, R. K.; THACKER, P. A.; NYACHOTI, C. M. Nutrient digestibility in diets containing low-phytate barley, low-phytate field pea and normal-phytate field pea, and the effects of microbial phytase on energy and nutrient digestibility in the low and normal-phytate field pea fed to pigs. Animal Feed Science and Technology, Amsterdam, v. 203, p. 79-87, 2015.

KIES, A. K.; KEMME, P. A.; SEBEK, L. B. J.; VAN DIEPEN, J. Th. M.; JONGBLOED, A. W. Effect of graded doses and a high dose of microbial phytase on the digestibility of various minerals in weaner pigs. Journal of Animal Science, Champaign, v. 84, n. 5, p. 1169-1175, 2006.

KIM, J. C.; SANDS, J. S.; MULLAN, B. P.; PLUSKE, J. R. Performance and total-tract digestibility responses to exogenous xylanase and phytase in diets for growing pigs. Animal Feed Science and Technology, Amsterdam, v. 142, n. 1-2, p. 163-172, 2008.

KIM, J. C.; SIMMINS, P. H.; MULLAN, B. P.; PLUSKE, J. R. The effect of wheat phosphorus content and supplemental enzymes on digestibility and growth performance of weaner pigs. Animal Feed Science and Technology, Amsterdam, v. 118, n. 1-2, p. 139-152, 2005.

LUDKE, M. C. M. M.; LÓPEZ, J.; LÜDKE, J. V.; NICOLAIEWSKY, S. Utilização da fitase em dietas com ou sem farelo de arroz desengordurado para suínos em crescimento/terminação. Revista Brasileira de Zootecnia, Viçosa, MG, v. 31, n. 5, p. 2002-2010, 2002.

MADRID, J.; MARTINEZ, S.; LÓPEZ, C.; HERNÁNDEZ, F. Effect of phytase on nutrient digestibility, mineral utilization and performance in growing pigs. Livestock Science, Amsterdam, v. 154, n. 1-3, p. 144-151, 2013.

MOEHN, S.; ATAKORA, J. K. A.; SANDS, J.; BALL, R. O. Effect of phytase-xylanase supplementation to wheatbased diets on energy metabolism in growing-finishing pigs fed ad libitum. Livestock Science, Amsterdam, v. 109, n. 1-3, p. 271-274, 2007.

NORTEY, T. N.; PATIENCE, J. F.; SIMMINS, P. H.; TROTTIER, N. L.; ZIJLSTRA, R. T. Effects of individual or combined xylanase and phytase supplementation on energy, amino acid, and phosphorous digestibility and growth performance of grower pigs fed wheat-based diets 
containing wheat millrun. Journal of Animal Science, Champaign, v. 85, n. 6, p. 1432-1443, 2007.

NYACHOTI, C. M.; ARNTFIELD, S. D.; GUENTER, W.; CENKOWSKI, S.; OPAPEJU, F. O. Effect of micronized pea and enzyme supplementation on nutrient utilization and manure output in growing pigs. Journal of Animal Science, Champaign, v. 84, n. 8, p. 2150-2156, 2006.

ORYSCHAK, M. A.; SIMMINS, P. H.; ZIJLSTRA, R. T. Effect of dietary particle size and carbohydrase and/ or phytase supplementation on nitrogen and phosphorus excretion or grower pigs. Canadian Journal Animal Science, Ottawa, v. 82, n. 4, p. 533-540, 2002.

PETER, C. M.; PARR, T. M.; WEBEL, D. M.; BAKER, D. H. The effects of phytase on growth performance, carcass characteristics, and bone mineralization of late-finishing pigs fed maize-soyabean meal diets containing no supplemental phosphorous, zinc, copper and manganese. Animal Feed Science and Technology, Amsterdam, v. 94, n. 3-4, p. 199-205, 2009.

POMAR, C.; GAGNÉ, F.; MATTE, J. J.; BARNETT, G.; JONDREVILLE, C. The effect of microbial phytase on true and apparent ileal amino acid digestibilities in growing-finishing pigs. Journal of Animal Science, Champaign, v. 86, n. 7, p. 1598-1608, 2008.

POULSEN, H. D.; BLAABJERG, K.; FEUERSTEIN, D. Comparison of different levels and sources of microbial phytases. Livestock Science, Amsterdam, v. 109, n. 1-3, p. 255-257, 2007.

POULSEN, H. D.; BLAABJERG, K.; STRATHE, A.; ADER, P.; FEUERSTEIN, D. Evaluation of different microbial phytases on phosphorous digestibility in pigs fed a wheat and barley based diet. Livestock Science, Amsterdam, v. 134, n. 1-3, p. 97-99, 2010a.

POULSEN, H. D.; CARLSON, D.; NØRGAARD, J. V.; BLAABJERG, K. Phosphorous digestibility is highly influenced by phytase but slightly by calcium in growing pigs. Livestock Science, Amsterdam, v. 134, n. 1-3, p. 100-102, 2010b.

ROSTAGNO, H. S.; ALBINO, L. F. T.; DONZELE, J. L.; GOMES, P. C.; OLIVEIRA, R. F.; LOPES, D. C.; FERREIRA, A. S.; BARRETO, S. L. T. Tabelas brasileiras para aves e suinos, composição de alimentos e exigências nutricionais de aves e suinos. Viçosa, MG: Universidade Federal de Viçosa, 2005. 186 p.

RUTHERFURD, S. M.; CHUNG, T. K.; MOUGHAN, P. J. Effect of microbial phytase on phytate $\mathrm{P}$ degradation and apparent digestibility of total $\mathrm{P}$ and $\mathrm{Ca}$ throughout the gastrointestinal tract of the growing pig. Journal of Animal Science, Champaign, v. 92, n. 1, p. 189-197, 2014.

SANDS, J. S.; KAY, R. M. Phyzyme XP phytase improves growth performance and nutrient utilization in wheat-based diets fed to weaned pigs. Livestock Science, Amsterdam, v. 109, n. 1-3, p. 264-267, 2007.

SANTOS, T. T.; WALK, C. L.; WILCOCK, P.; CORDERO, G.; CHEWNING, J. Performance and bone characteristics of growing pigs fed diets marginally deficient in available phosphorus and a novel microbial phytase. Canadian Journal of Animal Science, Otawa, v. 94, n. 3, p. 493-497, 2014.

SCHLEGEL, P.; NYS, Y.; JONDREVILLE, C. Zinc availability and digestive solubility in piglets and broilers fed diets varying in their phytate contents, phytase activity and supplemented zinc source. Animal, Cambridge, v. 4, n. 2, p. 200-209, 2009.

SCHLEMMER, U.; JANY, U. K. D.; BERK, A.; SCHULZ, E.; RECHKEMMER, G. Degradation of phytate in the gut of swine - Pathway of gastro-intestinal inositol phosphate hydrolysis and enzymes involved. Archives of Animal Nutrition, Berlin, v. 55, n. 4, p. 255280, 2001.

SELLE, P. H.; RAVIND4RAN, V. Phytate-degrading enzymes in pig nutrition. Livestock Science, Amsterdam, v. 113, n. 2-3, p. 99-122, 2008.

SHELTON, J. L.; SOTHERN, F. M.; LEMIEUX, F. M.; BIDNER, T. D.; PAGE, T. G. Effects of microbial phytase, low calcium and phosphorous, and removing the dietary trace mineral premix on carcass traits, pork quality, plasma metabolites, and tissue mineral content in growing-finishing pigs. Journal of Animal Science, Champaign, v. 82, n. 9, p. 2630-2639, 2004.

SILVA, D. J.; QUEIRÓZ, A. C. Análise de alimentos: métodos químicos e biológicos. 3. ed. Viçosa, MG: Universidade Federal de Viçosa, 2002. 235 p.

WOYENGO, T. A.; COWIESON, A. J.; ADEOLA, O.; NYACHOTI, C. M. Ileal digestibility and endogenous flow of minerals and amino acids: responses to dietary phytic acid in piglets. British Journal of Nutrition, Cambridge, v. 102, n. 3, p. 428-433, 2009.

ZHANG, Z.; NYACHOTI, C. M.; ARNTFIELD, S.; GUENTER, W.; CENKOWSKI, S. Effect of micronization of peas and enzyme supplementation on nutrient excretion and manure volume in growing pigs. Canadian Journal of Animal Science, Ottawa, v. 83, n. 4, p. 749-754, 2003. 
